\title{
Introduction
}

\section{Reconstructing the Author}

Once Zhuang Zhou dreamed of himself being a butterfly; he was really a butterfly fluttering around, happy and comfortable, knowing not that he was Zhou. After a while, he woke up, and he was surprisingly Zhuang Zhou himself. It was not clear whether it was Zhou who had dreamt of being a butterfly or it was the butterfly who had dreamed of Zhou. Yet there must be differentiation between Zhou and the butterfly, and this is called the transformation of things.

Zhauangzi, i, pp. 53-4

Do we dream or are we dreamt? Might we dream and be dreamt? When an author writes or thinks to be writing, is that author simultaneously written? Does creative imagination guide the composition, or is the writer like the scrawl of an alien power trying out a new pen? Are the 'great authors' masters in the house of language, or its privileged tenants? Is the author the producer of the text or its product? Do we speak language or does language speak us? Does the author reflect culture and history, or is the author constructed in culture and history?

These questions have been raised in a myriad tongues and lexicons throughout the history of Western thought, and every attempt to decide the issue one way or the other has only served to rejuvenate the debate, to play it out in a different key. Authorship, like cosmology, remains a source of fascination for believers and non-believers alike since the issues which it raises reflect any given society's sense of being in the world, and construction of itself in relation to discourse, 
knowledge and tradition. Notions of the self, creativity, psyche, origin, source, theology, onto-theology, agency, free will, determinism, consciousness, causality, gender, cultural identity, objectivity, subjectivity, ownership, authority (scarcely to exhaust the list) are implied not only by the question of authorship but also by theories of the absence, death or disappearance of the author. The very movement against the author precipitated in 1968 by Roland Barthes's 'The Death of the Author' served, albeit antithetically, to remind us of the extent to which the history of our thought is bound up with conceptions of what it means to author a text. With unavoidable irony, the theory of authorial absence no more signalled a disengagement with issues of authorship than iconoclasm attests to the dwindling of the icons, or negative theology reflects an indifference to Divinity. The ancient chimeras of origin and authorship reassert themselves in the very gestures that seek to have done with origin and authorship.

Harold Bloom avers that 'meaning ... cleaves more closely to origins the more intensely it strives to distance itself from origins', and the putative emptying-out of the authorial subject has been caught up in an asymptotic cycle of resistance to the transcendental presuppositions which it sought to erase. ${ }^{1}$ The project of radically impersonalising discourse has obvious precedents in the mimetic tradition which, in both its idealist formulation and in the quasi-scientific literary naturalism of Zola and others, implies the total absenting of authorial subjectivity in the interests of an unmediated representation of objective reality. Barthes refers to this tradition as 'the castrating objectivity of the realist novelist' and redefines modern impersonality in antimimetic terms as 'that point where only language acts, "performs", and not "me" '. ${ }^{2}$ However, while this position easily avoids the disinterestedness of Platonic and naturalist objectivity, it admits of very little distinction from the inspirational tradition of Classical, Patristic and Medieval theory. Within the Medieval view of the book, the author (or auctor) was the scriptor through whom the Divine script was performed. As the exegete Nicholas of Lyre (c. 1270-1340) puts it:

In the act of prophesying, God (touching or elevating the mind of the prophet to supernatural knowledge) and the mind of the prophet (touched or illuminated in this way), concur. It is necessary that the moving action and the thing moved should coincide . . God concurs as the principal agent, and the mind of the prophet as the instrumental agent. ${ }^{3}$ 
Within the Medieval view, the human author of Scripture has no power to originate, and his text derives from the creativity and authority (auctoritas) of God. Thus when Foucault describes the Mallarméan author as 'an executant in a pure ceremony of the Book in which the discourse would compose itself, the distinction between such a role and that of the Scriptural auctor resides only in the designation of the alterity by which the recipient is overtaken. ${ }^{4}$ Similarly, the impersonal scribe with whom Barthes would replace the author only differs from the auctor in that language is sacralised in the wake of the Divine auctoritas:

the modern scriptor ... is not the subject with the book as predicate; there is no other time than that of the enunciation and every text is eternally written here and now ... For him, on the contrary, the hand, cut off from any voice, borne by a pure gesture of inscription (and not of expression), traces a field without origin - or which, at least, has no other origin than language itself, language which ceaselessly calls into question all origins. ${ }^{5}$

We need only for 'language' substitute 'God' here to replicate precisely the dominant Medieval view of the auctor who, 'borne by a pure gesture of inscription (and not of expression), traces a field without origin - or which, at least, has no other origin than God Himself, God who ceaselessly calls into question all origins." The notion of a divided authorial psyche - and the consequent inability of the writing subject's intentions to become fully present to themselves in the text - is also resplendently anticipated in the Classical and Medieval traditions. While Plato and the writer known as 'Longinus' emphasised that poetry found its wellsprings in a frenzying visitation inaccessible to consciousness - the former perhaps ironically, the latter with conviction - Biblical exegesis, seeing Scripture as emanating from that most radical of alterities, the Divine Will, fully accepted that authorial intention (intentio auctoris) could be at most a concause in the texts, coming into being. Nonetheless, Christian exegetes developed sophisticated and intricate critical apparatuses to allow for a complex interplay of multiple determinants - including the role of the auctor - in the constitution of the Scriptural text. Seen from this vantage, the contemporary deployment of the various declensions of 'otherness' developed within theory - the unconscious, cultural or political forces, écriture, differance, etc. - distinguishes itself from the Medieval tradition mainly through an inability or unwillingness to acknowledge the overdetermination of a textual scene which encompasses alterities and the participant role of the author. 
Indeed, the very term auctor (from which author is derived) was very late to garner the connotations of originality with which it is today (dis)credited. ${ }^{6}$ Of the four terms from which auctor is held to derive, the three Latin verbs do not imply any sense of textual mastery. Agere, 'to act or perform', is close to the Medieval and Barthesian ideas of the scriptor as acting through a text which in some sense precedes its performance; augere, 'to grow', for all its organicist resonances, does not suggest that the text originates with its author. Auieo, 'to tie', derived from the poetic lexicon and referred to the connective tissue (metre, feet, etc.) by which poets such as Virgil structured their verses in which regard it is more prefigurative of the structuralist notions of bricolage and authors as assemblers of codes than the concept of the author as a creative potency. Only the fourth root, the Greek noun autentim, 'authority', is suggestive of authorship as hegemonic, and even here the idea of authority is entirely remote from that of autonomy since the ancient authors received their authority (auctoritas) in the first instance from their relation to tradition and ultimately from the auctoritas of God as manifested inspirationally and in the Scriptural canon. If the Medieval view of the book could be unanchored from its theological moorings, it is unlikely that anti-authorial theories would find much to contest in this structural placement of the author.

Many theorists have of course been aware that the contemporary repudiation of the author echoes the ancient view - Barthes even talks of the 'modern scriptor' - but tend to appropriate the older view of authorship in order to celebrate the void of the abolished humanist author rather than to consider how our notions of authorship might be productively revised. What distinguishes premodern conceptions of authorship is their assumption that discourse is primarily an affair of public rather than private consciousness. The various imitative models - in their mimetic, didactic and technical senses - all affirm literature's connection with the public domain, whether that domain consists in an objective reality renderable by language, a shared vision of how the social should be restructured, or in terms of public conventions and traditions for the production and reception of discourse. The inspirational model assumes still more strenuously that discourse neither originates nor culminates with the individual since the author functions as an avatar of a Divine writing addressed to all humankind - hence its evangelical emphasis on wide dissemination, be it written or declaimed. So far from endorsing an interiority that feeds from itself back into itself, the inspirational tradition affirms that discourse is not a private intuition but a public revelation. Were it possible, in Barthes's 
famous phrase 'the birth of the reader must be at the cost of the death of the author', to take 'reader' as a synecdoche for 'public' and 'author' for 'interiority', then the movement against the author would gain greater coherence in cultural and political terms as well as a clearer sense of historical mission.

The movement against the author did not present itself in such terms, however, instead advocating a 'Reader' no less ambiguous and mystified than the 'Author' whom it sought to supplant. Given then that anti-authorial theory neither develops significantly upon the ancient conception of authorship nor returns discourse to the public sphere, I would suggest that the crucial historical change in conceptions of authorship did not occur in the theoretical upheaval of the last thirty years but with the romantic revolution and the eighteenth-century philosophical and aesthetic discourses upon which it drew. I would also suggest that it is to the very romantic tradition against which theory aligns itself that the Death of the Author belongs, even if it should do so inadvertently, and as its final term.

THE TRANSCENDENTAL AND THE IMPERSONAL

All too often, the idea of a 'break' or 'rupture' in thought asserts radical discontinuity in place of the subtler modes of realignment by which an age or epoch inherits traditional categories while decisively modulating their relations. It would, for example, be no more true to say that the mimetic impulse declines in romanticism than to claim that authorial originality or a concern with interior consciousness arose unprecedented in the late eighteenth century. The notion of a writer defying or transcending tradition - evident in the Renaissance celebration of Genius $^{7}$ - had been clearly prefigured in work of Edward Young, William Duff and others who championed original productions over neo-Classical imitation. Similarly, the subjectivist strivings of Montaigne for self-representation, along with the exploration of interior consciousness in Descartes and the thinkers of the Enlightenment, defy reduction to any such comfortable periodic tablature even if these untimely meditations had yet to pervade aesthetic awareness. What makes these continuities appear under the sign of epistemic discontinuity, however, is the power newly assigned by the romantics to individual consciousness in the creation of a world which it had hitherto been assumed to mirror or represent. The work of Young, Duff and others will seem to us 'preromantic' since their model of originality is defined reactively via tradition rather than in terms of a theory of interior consciousness as constitutive of the reality which it 
seeks to represent. Such a recognition - which required the most radical restructuring of the relation between consciousness and its objects only became possible with Immanuel Kant, whose 'Copernican Revolution' asserted that the only world we know is the world we construct through innate mental categories.

For Kant, the world we perceive is only made possible to us through the operations of a transcendental ego which imposes the a priori categories of space, time and causality upon the ultimately inaccessible objects of experience. While Kant developed transcendental idealism in strictly epistemological terms, however, the concept of a subjectivity which originates the world given to it in consciousness promoted dynamic, if not always precise, analogies with artistic creativity. In what was perhaps the inaugural move of romantic idealism, Fichte and Schelling sought to make aesthetically and metaphysically substantive what was in Kant an epistemological postulate. Kant's demonstration that the world of experience is not in itself given to consciousness served to problematise the mimetic subordination of author to nature; the constructive function of the transcendental ego, on the other hand, invited at least metaphorical extension into the aesthetic realm via a model of imagination as shaping and (re)creating the world in poetic language. Shelley, for one, was to make the brightest claims for this function of the imagination: 'It creates anew the universe after it has been annihilated in our minds by the recurrence of impressions blunted by repetition'. 8

Within a poetic cosmogony wherein mind becomes the cause in part of what it represents, the older categories of imitation and inspiration do not disappear but rather find themselves redistributed within the new economy of subjectivity. The mimetic role of poetry remains pronounced in Wordsworth, for example, but is now in consort with an unprecedented emphasis on the reciprocal fecundity of the imagination in what he calls 'an ennobling interchange/Of action from within and from without'. ${ }^{9}$ Nature is no longer simply given but is in need of aesthetic completion. 'How exquisitely', Wordsworth declared, 'the individual Mind / . . . to the external World'

Is fitted: - And how exquisitely, too . . .

The external world is fitted to the Mind;

And the creation (by no lower name

Can it be called) which they with blended might Accomplish . . . 10 
Nature is now dependent upon the epiphanic power of the creative imagination for its poetic reproduction. The imagination is therefore needed to supplement nature, to reveal the truth of a nature which cannot precede its imaginative representation. Given that mind must therefore represent itself in the act of representing reality, the exploration of interior consciousness becomes a calling no less Olympian and sublime than the Miltonic theme of Creation and Fall:

\section{Not Chaos, not}

The darkest pit of lowest Erebus,

Nor aught of blinder vacancy, scooped out

By help of dreams - can breed such fear and awe

As fall upon us often when we look

Into our Minds, into the Mind of Man -

My haunt, and the main region of my song. ${ }^{11}$

This radical exploration of the interior recesses of mind could not but reveal areas of intuition alien to consciousness or artistic control, with the result that questions of inspiration and alterity arduously reasserted themselves within romantic aesthetics. The renewed interest in inspiration did not, however, present itself as disjunct with the emergent category of imagination. The very idea of an 'inspired creator' resonated in romanticism with far fewer of the oxymoronic tensions which we would today discern in such a conceit: inspiration was set alongside rather than against the creative, originating imagination. Even a poem such as 'Kubla Khan', with its extreme weighting towards the unconscious, closes by hearkening for a state of inspiration mastered, and the productive reconciliation of the subject and alterity. Whether indeed inspiration is bounded by the self in the form of a Wordsworthian 'inner voice', or treated in Shelleyan terms as adnascent with the creative imagination, it is always in some sense thought of in terms of the individual subject and never as the radical alterity of the Patristic and Medieval traditions. Coleridge in fact makes of the reconciliation of the subject and alterity a famous formula:

The IMAGINATION then I consider either as primary, or secondary. The primary imagination I hold to be the living Power and prime Agent of all human Perception, and as a repetition in the finite mind of the eternal act of creation in the infinite I AM. ${ }^{12}$

The ancient association of human and divine creativity is maintained but has been subjected to an unprecedented reversal. The author is no longer a privileged reader of the Divine script in nature, nor an elect 
who inspirationally mimes the Divine discourse, but is now seen as imitating the act of creation itself. Such a reversal is registered perhaps too crudely in Herder's assertion that 'The author is become a CreatorGod', ${ }^{13}$ but emerges influentially in Schiller's celebration of the objective cast of Classical (naïve) authorship:

without intimacy [the naïve poet] flees the heart that seeks his, flees the desire that would embrace him . . . The object possesses him entirely, his heart does not lie like a tawdry alloy immediately beneath the surface, but like gold waits to be sought in the depths. Like the divinity behind the world's structure he stands behind his work; he is the work and the work is he; to ask only for him is to be unworthy of it, inadequate to it, or sated with it. ${ }^{14}$

The transcendence of the author here carries a concomitant impersonality. This dual stress has much in common with the subject of Kantian idealism which is both transcendent of the world and ontologically hollow. It can also be retraced - as M. H. Abrams suggests - to the theological tradition which portrays God as both transcendent of, and omnipresent within, creation. ${ }^{15}$ As translated into literary terms, the author can be identified with the entirety of the work while being nowhere visible within the work. The will to impersonalise literary creation, though often downplayed in cursory constructions of the Romantic period, is also to be discerned in Keats's idea of negative capability - an empathetic act which requires the emptying-out of all personal concerns in poetic composition - as well as in Coleridge's insistence that 'to have a genius is to live in the universal, to know no self . . ${ }^{16}$ It is also a central edict in later German romantics such as K. W. F. Solger for whom artistic creation is requisitely objective, ironic and impersonal. ${ }^{17}$

One might of course ask why these seemingly contradictory impulses - towards subjectivity on the one hand, and impersonality on the other - should coincide at the very outset of the era of subjectivity. A possible explanation, I would suggest, is that impersonality functioned as a guard against the potentially nihilistic implications of Kant's subjective idealism, as an attempt to preserve something of the Enlightenment notion of disengaged reason in an era which could no longer see truth as mimetically grounded or divinely sanctioned. Precisely this vigilance informs Kant's Critique of Judgement, which proceeds from the recognition that the determining ground of judgement can be no other than subjective, to the injunction that such judgements involve 'detachment from all interest' and thereby lay 
claim to 'subjective universality'. ${ }^{18}$ Impersonality, like disinterestedness, would seem then to arise as a reflex or defence in simultaneously acknowledging the ascendance of subjectivity while guarding against its more destabilising ramifications.

This very same need to defend against the subjectivist turn in modernity informs modernist reactions against personality. The notion of literature as a revelation of personality had dominated criticism in the latter half of the nineteenth century and - bolstered by the emergence of popular psychology - served to justify a mixed and rhapsodic discourse which saw no contradiction in uncovering an author's personal life at the same time as lauding that author's transcendent genius. However, while the modernist aesthetic quite rightly countered this development, the strongest arguments of Eliot, Hulme, Pound and others often reclaim the higher romantic ground in the process of declaring their anti-romanticism. Schiller's depiction of the impersonal Author-God reappears with scarcely discernible modifications in the protomodernist reflections of Flaubert, for whom ' $[t]$ he author in his work ought to be like God in the universe, present everywhere, and visible nowhere', which were in turn to form the blueprint for the image of the modernist writer as disinterested artificer. ${ }^{19}$

T. S. Eliot's theory of impersonality likewise calumniates one strand of the romantic movement even as it corrects another. His famous dictum that poetry 'is not the expression of personality, but an escape from personality ${ }^{20}$ has the clearest affinities with Schiller's celebration of the poet who 'flees the heart that seeks his, flees the desire that would embrace him'. Similarly, Eliot's insistence that 'the more perfect the artist, the more completely separate in him will be the man who suffers and the mind which creates'21 not only echoes Keatsian negative capability but must also recall Coleridge's praise of Shakespeare in terms of the 'utter aloofness of the poet's own feelings, from those of which he is both the painter and analyst'. ${ }^{22}$ No less than within romanticism, the reaction against subjectivity once more shows that its terms are governed by the era of subjectivity.

A similar structure of continuity in resistance emerges in the general reading of the New Criticism's development of impersonalist theory. Given that a transcendental/impersonal subject is not figured within the text, it is a long historical but short conceptual step to displace the autonomy of the subject into the text itself. In both romantic and modernist aesthetics, impersonality had for the most part described a mode or mood in which an author achieved aesthetic transfiguration. According to the dominant (though often problematic ${ }^{23}$ ) reception of 
the New Criticism - whose lineage combines modernist impersonality with the Kantian stricture of aesthetic disinterestedness - the refusal to confine criticism within a model of literature as self-expression transposes itself from an issue of writing to one of reading. Objectivity becomes not so much a matter of how the text is constituted but of the responses which it should properly provoke. Poetic autonomy thereby preserves the autonomy of the author in the same gesture by which it evacuates the author. The impersonal reflex comes to dominate the scene of reading as well as that of writing, and once more arises as a reactive inversion of the transcendental dynamic in which it is constituted.

In this light, one could read 'The Death of the Author' as the latest instance of the impersonalising tendency in modernity whereby 'writing' rather than the lone text of Anglo-American formalism now becomes the privileged category which serves to distance the text from its authorial subject. The very manner in which 'The Death of the Author' oscillates between the performative and the descriptive, between viewing itself as the moment of the author's death and its contrary urge to establish precedents, attests to an anxious sense of continuity. The 'requisite impersonality' which Barthes champions is distinct from the realist canon of objective mimesis, but clearly cannot distinguish itself from the impersonalities of a Flaubert, Mallarmé or Valéry and hence from the high romantic conception of disinterested subjectivity. Indeed, as Michel Foucault betimes declared: '[écriture] has merely transposed the empirical characteristics of an author to a transcendental anonymity'. ${ }^{24}$ Clearly, Barthes's essay does not escape from the transcendental/impersonal impasse of modernity by its extreme weighting to the latter term. While, however, we cannot read 'The Death of the Author' on its own terms as a step beyond the subjective horizons of high modernity, we might see it as a crisis within the impersonalising tradition, as the point where impersonality so oversteps the mark in the direction of the reductio ad absurdum as to force its own breach and to beckon something other than itself into being.

But what might that 'something other' be? The foregoing would seem to suggest that there is no way out of the play of transcendence and impersonality beyond that of making an unlikely and unwelcome return to biographical positivism or unreflective humanist models. I would suggest, however, that late modernity's profound unease about the subject can only be addressed through the subject and in terms which respect many of the objections made to the humanist author. I would also suggest that the only way of fulfilling the implicit demands 
of the Death of the Author consists in returning to the question of the author. Such a return implies further that the ontologies of the author and the subject might provide a positive space for those general crises in thought that announce themselves as the postmodern. Certainly, it is only through reciprocal enquiry that the dilemmas of postmodernism and subjectivity can arrive at fuller senses of themselves; less clear is the question as to which of these spaces waits in greater need of the other.

\section{SITUATING THE SUBJECT}

The first vigorous challenge to the Kantian notion of a transcendental subject came in the work of Friedrich Nietzsche, who advocated a return to the body against impersonal or disembodied consciousness. For this reason, among others, Nietzsche has been taken up as the most significant precursor of both postmodern and theoretical critiques of Enlightenment modernity. While Nietzsche's deconstruction of transcendental subjectivity is assumed as the starting point for contemporary thought, very little heed is paid to the procedure which made such a critique possible in the first place. So far from asserting an anonymity of discourse against the Cartesian and Kantian subjects, Nietzsche disputed the model of transcendence through his assertion that discourse is inalienably personal, that philosophical authorship operates in the mode of self-erasure via rhetorical and conceptual strategies which distract both author and reader from the fact that knowledge and textuality are altogether rooted in the singularity of subjective concerns. Beyond its epistemological destinations, the characteristic Nietzschean interrogation ('Who is speaking? And why speaking thus?') also opens the space of a stringent ethical critique by retracing a text first to its author and thence to the ethical drives which motivated that text or system. Only by opening the text to its author in such fashion was Nietzsche able to uncover a fundamental will-to-power behind the façade of disinterested will-to-knowledge.

Following upon Nietzsche, the most radical alternatives to transcendental subjectivity have sought to situate rather than detach the subject from its work and world. For Freud, impersonality is a defence against an inescapable, almost unbearable situatedness in terms of personal desire, memory, biography. Within the Freudian model, every attempt at disinterestedness or transcendence is fated to collapse as the unconscious resituates and returns author to text, subject to discourse, and the traumatically personal to the defensive will-to-impersonality. Marx's opposition to the subject as 'the merest vapourings of idealism' likewise set out not to convert implicit into explicit absence but to demystify 
discourse via the author: as he and Engels made clear, one can only 'enthuse over the miracle-working of the pen' by divorcing the text from the 'living historical human subject' by whom it was produced. ${ }^{25}$ In Heidegger, as in the other grand precursors of theory, contemporary receptions have similarly scored the deconstruction of the 'view from outside' over its corollary replacement by a situated subject, a historically full ' $I$ ' in contradistinction to the ontologically void ' $I$ ' of the Kantian analytic. As with Nietzsche and Freud, Heidegger's thought would be taken up with altogether more fidelity as a return of subject to world, author to text and one which is quite in defiance of not only the objective overseer of science, the omniscient subject of representation or the impersonal artificer of high modernist aesthetics, but also of the authorless discourse to whose elaboration his name is so often summoned. What in fact occurs in many theoretical appropriations of these discourses is that modernity's disengaged subject is challenged only through proposing a further locus of disengagement which neglects the fact that Nietzsche and Heidegger more or less explicitly opposed the Author through the author, the Subject through the subject. Jacques Derrida, in a recent interview, draws attention to these two aspects of this critique but does so under the signs of their discrepancy rather than their complicity:

At the very moment in which they marked . . . their mistrust for substantialist or subjectivist metaphysics, Heidegger and Nietzsche, whatever serious differences there may be between the two, continued to endorse the question 'Who?' and subtracted the 'who' from the deconstruction of the subject. But we might still ask ourselves just how legitimate this is. ${ }^{26}$

The move - to my mind - is entirely legitimate since Nietzsche and Heidegger did not subtract the 'who' from the deconstruction of the subject but protracted their deconstruction precisely on its basis. The question 'who' ('is writing?'; 'is reading?') was destined to challenge generic subjectivity via the perspectivism of the situated subject so as to unmask the personal drives behind the abstract system. One can see that so many of the problems that bedevil the author-debate arise from the failure to realise that the notion of the author has been falsely analogised with the transcendent/impersonal subject and that the only way to deconstruct this latter subject is not to replace it with theories of language, différance, anonymity, écriture féminine and so on, but to reposition authorship as a situated activity present not so much to itself as to culture, ideology, language, difference, influence, biography. 
Contemporary deconstructions of the subject themselves imply and yet recoil from such an undertaking. The deconstructive dismantling of the stable subject of romantic irony provides the opening for a repositioning of authorship even as it declares the concept of the author to be overrun by textual indeterminacy. As David Simpson and others have astutely demonstrated, the romantic conception of a transcendental subjectivity which holds in place all of a text's contradictions, while ironically commenting on their play, affirms a paradigm of metacommentary which is untenable even in its own terms. ${ }^{27}$ Given the impossibility of transcending romantic oppositions such as eternal/ temporal, art/impermanence, the metacommenting position must in its turn be ironically disrupted by textual forces which exceed and elude its assumed mastery. Ironic metacomment is therefore collapsed into comment in such manner that neither formal closure nor aesthetic completion is any longer possible upon this ironic trumping of the ironising subject. However, thus to collapse the authorial metacomment back into comment does not necessarily remove the romantic subject from the overdetermined scene of his or her text. Faced with the toppling of the transcendental position into this 'irony of irony', one might equally infer the consequent embedding or situating of the authorial subject within rather than outwith the ironic competitions of the text. Such a relocation would move from impersonal detachment to personal engagement within a textual scene whose undecidability admits neither of authorial mastery nor of authorial disappearance. A view of subjectivity thus arises which is neither a limit nor a limiting concept but one which enables reading to pass beyond the constraining play of transcendence and disappearance.

Deconstruction is by no means unique in simultaneously suggesting and forestalling openings for a reconsideration of authorial subjectivity. Foucault's movement from an archaeological to a genealogical approach was dictated in part by the recognition that theoretical impersonalities reinvoke the transcendental presuppositions of modernity: such a reorientation implied the turn towards a model of situated authorial subjectivity which his discourse never quite explicitly takes. Similarly, the concerted return to context which we have recently witnessed in the discourses of New Historicism, Cultural Materialism and Postcolonialism suggest the restoration of a working concept of authorship if only to provide a point of access to historical, cultural and colonial contexts. Quite often, in fact, these discourses proceed covertly through the author while disclaiming the author with an embarrassment which presumably stems from too heavy and 
reactive an investment in modernity's characterisation of authorship as autonomous agency. The current contextualisation of political criticism would itself seem to beseech a restoration of situated agency and one which may not indefinitely bypass authorship if only because resistance and agency so often proclaim themselves in the form of written texts.

It is indeed no less difficult to see the renewal of context in ideological criticism as anything other than a legitimate and long-awaited response to the disarming effects of linguistic determinism than it is to envisage a future of effective political criticism without the vigorous rehabilitation of the referent. Similarly, the scission of sign and referent - and further that of signifier and signified - cannot but be related to the altogether more disabling than disabusing separation of author and text. Depriving discourse of authorship and agency has been gravely debilitating within Marxist and feminist criticism, and ironically so since feminism in particular offers such potentially productive resources for redefining subjectivity outwith and against the model of autonomy. As Nancy K. Miller writes:

Because women have not had the same historical relation of identity, to origin, institution, production that men have had, they have not, I think, (collectively) felt burdened by too much self, ego, cogito, etc. Because the female subject has juridically been excluded from the polis, hence decentred, 'disoriginated', deinstitutionalised, etc., her relation to integrity and textuality, desire and authority, displays structurally important differences from that universal position. ${ }^{28}$

What is true for feminism in this context would also apply to the postcolonial challenge to the 'universal position' which has reified its own European preoccupations into a global model of subjectivity. Furthermore, the second-order post-colonial critique of a hypostasised colonial subject would imply as its positive counter a defence of the specificity of the subject, the grounding of the text in the irreducible personal and cultural experiences of its author. In each case, a rigorous rejection of the universal subject must imply a reassertion of the subject in his/her particularity. ${ }^{29}$

The need to (re)situate subjectivity is prime among the many callings facing political theories as well as those facing the cluster of discourses we refer to as the postmodern. To refuse totalising histories or accounts of human nature should be itself to refuse the impersonalising consciousness that purportedly enables such stories to be told. The challenge to truth or truth effects must likewise be a challenge to the 
disengaged subjectivity which generates such a discursive effect in the first place, whether that effect arises through the neutrality of scientific observation, the panoramic consciousness of realism, or the grand philosophical narratives of history and thought.

Conversely, and by the same token, postmodern emphases on 'islands of discourse', on little narratives, language games, the locality of discourse, should acknowledge the situated author as principle of locality par excellence. When we consider that the war on totalities must be a war waged on the transcendental/impersonal subject through whose putative construction totalities emerge, it becomes clear that the great crises of postmodernism are crises of authorship even if they still disdain to announce themselves as such. The difficulties of envisaging how and where contemporary thought might relocate the authorship that is everywhere in its midst may only be outweighed by the necessity of the calling and should in no wise deter us from the attempt. In any eventuality, and as postmodernity slouches towards the millennium, it is clear that this project - glimpsed by Nietzsche more than a century ago - still lies before us.

\section{NOTES}

Epigraph Quoted in Zhang, Longxi, The Tao and the Logos: Literary Hermeneutics, East and West (Durham and London: Duke University Press, 1992), p. 150.

1. Harold Bloom, A Map of Misreading (New York and London: Oxford University Press, 1975), p. 62.

2. Roland Barthes, 'The Death of the Author', Image - Music - Text, trans. and ed. Stephen Heath (London: Fontana, 1977), pp. 142-8: p. 143.

3. Nicholas of Lyre, quoted in A. J. Minnis, Medieval Theory of Authorship: Scholastic Literary Attitudes in the Later Middle Ages (London: Scolar Press, 1984), p. 91.

4. Michel Foucault, The Order of Things: An Archaeology of the Human Sciences, trans. Alan Sheridan (London: Tavistock, 1970), p. 306.

5. Roland Barthes, 'The Death of the Author', op. cit., pp. 145-6.

6. Sec, for example, the etymo-critical account of authorship and authority in Edward Said, Beginnings: Intention and Method (Baltimore, MD: Johns Hopkins Univcrsity Press, 1975), p. 83. The relevant passage is quoted below by Gilbert and Gubar in Part 2, Section 1.

7. As the seminal work in the cultural rise of the notion of genius, see Giorgio Vasari, The Lives of the Artists [1550 and 1568], trans. and ed. Gcorge Bull (Harmondsworth: Penguin, 1965).

8. Percy Bysshe Shelley, 'A Defence of Poetry', in The Norton Anthology of English Literature, 5th cdn, vol. 2, pp. 778-92: p. 790.

9. William Wordsworth, The Prelude, ed. E. de Sclincourt (Oxford, 1926), XIII, 11. 375-6. Sce also Charles Taylor's excellent work for a detailed account of the Romantic notion that imagination epiphanically completes nature: Charles Taylor, Sources of the Self: The Making of the Modern Identity (Cambridgc: Cambridge University Prcss, 1989), pp. 368-90.

10. William Wordsworth, 'Preface to The Excursion', in The Poetical Works, ed. E. de Selincourt and Helen Darbishire (Oxford: Clarendon Press, 1949), V, 11. 63-71.

11. Ibid., 11. 35-41.

12. Samuel Taylor Colcridgc, Biographia Literaria I, cd. James Engell and W. Jackson Bate, Bollingen Scrics LXXV (Princeton, NJ : Princeton University Press, 1983), p. 304. 
13. Johann Gottfricd Herder, quoted in Tzvetan Todorov, Theorie du Symbole (Paris: Editions du Scuil, 1977), p. 175.

14. Fricdrich Schiller, 'On Naïve and Sentimental Poctry', trans. Julius A. Elias, in David Simpson, The Origins of Modern Critical Thought: German Aesthetic and Literary Criticism from Lessing to Hegel (Cambridge and New York: Cambridge University Press, 1988), pp. 148-73: p. 156.

15. Scc M. H. Abrams, The Mirror and the Lamp: Romantic Theory and the Critical Tradition (London: Oxford Univcrsity Press, 1953), pp. 239-41.

16. Samucl Taylor Colcridgc, The Philosophical Lectures, cd. Kathlcen Coburn (London, 1949), p. 179.

17. On K. W. F. Solger's impersonal acsthetic, sec David Simpson, The Origins of Modern Critical Thought: German Aesthetic and Literary Criticism from Lessing to Hegel (Cambridge and New York: Cambridge University Press, 1988), pp. 319-28; and Renć Wellck, A History of Modem Criticism 1750-1950, 2. The Romantic Age (London: Jonathan Capc, 1955), pp. 298-303.

18. Immanucl Kant, The Critique of Judgement, trans. James Creed Mercdith (Oxford: Oxford University Prcss, 1952), pp. 50-1.

19. Cf. Gustave Flaubert, Correspondence II, cd. Eugene Fasquelle (Paris, 1900), p. 155.

20. T. S. Eliot, 'Tradition and the Individual Talent', in The Sacred Wood: Essays on Poetry and Criticism (London: Mcthuen, 1920), pp. 47-59: p. 58.

21. Ibid., p. 54.

22. Samucl Taylor Colcridge, Biographia Literaria II, op. cit., p. 22.

23. The New Criticism was in fact a rather more complex cluster of discources than cither its general reception or its theoretical reconstitution would suggest - the latter usually serving mercly as summary prologuc to its rejection.

24. Michel Foucault, 'What is an Author?', in Michel Foucault, Language, Counter-Memory Practice: Selected Essays and Interviews, cd. Donald Bouchard, trans. Donald Bouchard and Sherry Simon (Ithaca, NY: Corncll University Press, 1977), pp. 113-38: pp. 119-20.

25. Karl Marx, The German Ideology I (London: Lawrence and Wishart, 1970), pp. 84-5. For a comprchensive selection of the acsthetic obscrvations of Marx and Engels, sec Karl Marx and Fricdrich Engels, On Literature and Art: A Selection of Writings, ed. Lec Baxandall and Stefan Morawski (New York: International Gencral, 1973).

26. Jacques Derrida, “"Eating Wcll”: An Intcrvicw', in Who Comes after the Subject?, cd. Eduardo Cadava, Pcter Connor and Jean-Luc Nancy (New York and London: Routledge, 1991), p. 101.

27. In following here David Simpson's cxcellent work in this ficld, I do not mean to disputc his demonstration, mercly to show how it could nudged towards the median conception of subjectivity which I recommend in general. Sec David Simpson, Irony and Authority in Romantic Poetry (Totowa, NJ: Rowman and Littlefeld, 1979).

28. Nancy K. Miller, Subject to Change: Reading Feminist Writing (Ithaca, NY: Corncll University Press, 1988), p. 106.

29. Scc, for cxample, Gayatri Chakravorty Spivak, 'Can the Subaltcrn Spcak?', in Colonial Discourse and Post-Colonial Theory: A Reader, cd. and introduced by Patrick Williams and Laura Chrisman (Hemel Hempstead: Harvester, 1993), pp. 66-111. 